\title{
A morphological study on the carotid body of the Angora rabbit
}

\author{
Emrullah Eken ${ }^{1}$, Kamil Beşoluk ${ }^{1}$, Hasan Hüseyin Dönmez ${ }^{2}$ Murat Boydak ${ }^{2}$ \\ ${ }^{\prime}$ Department of Anatomy, Faculty of Veterinary Medicine, University of Selçuk, Konya, Turkey \\ ${ }^{2}$ Department of Histology and Embryology, Faculty of Veterinary Medicine, University of Selçuk, Konya, Turkey
}

\begin{abstract}
The aim of the present study is to reveal the morphological structure of the carotid body of the Angora rabbit. For this purpose a total of thirteen adult Angora rabbits were used. In 5 Angora rabbits the carotid body was located in the periarterial connective tissue between the occipital and the caudal auricular arteries, but in 2 animals between the maxillary and the caudal auricular arteries. This connective tissue that enveloped the carotid body like a capsule divided the organ into numerous lobes by radiating into its parenchyma. In histological examinations the organ contained dark and light coloured nuclei that are divided into type I and type II, respectively. Type I cell that looked like a paraganglion structure was located around vessels and had large, round and oval-shaped nuclei, and contained pinkish granule in its cytoplasm. Type II cell was localized around type I ones and had long and dark coloured nuclei, which were located slightly off centre and 1-3 in number, and were full of cytoplasmic vacuoles. It has been proposed that this work may shed light on experimental hypoxia related studies by describing the exact morphology of the carotid body of Angora rabbit.
\end{abstract}

Key words: carotid body; glomus caroticum; morphology; rabbit

Anatomy 2008; 2: 49-54, (c) 2008 TSACA

\section{Introduction}

Angora rabbits (Oryctolagus cuniculus), one of the oldest known domesticated breeds of rabbit, is a species of the order Lagomorpha. They were introduced into Europe from the town of Ankara in Turkey, towards the end of the eighteenth century. Its long wool was selectively bred over hundreds of years and is called Angora fibre. Angora fibre production is the third largest animal fibre industry in the world after wool and mohair. ${ }^{1}$

The carotid body is highly specialized organ located at the common carotid artery bifurcation. It was first anatomically described by Albrecht Von Haller in $1743 .^{2}$ The term paraganglion was first used by histologist Kohn to describe the carotid body. ${ }^{3}$ Histologic studies of the carotid body revealed glandular acini so the carotid body was renamed the carotid gland. In the early part of the 20th century, other structures were found throughout the body that was histologically similar to this carotid gland. The gland was renamed a vascular glomerulus or glomus. The term glomus today refers to any collection of specialized tissue.

The carotid body (Glomus caroticum) is derived from mesodermal elements of the third branchial arch, which give rise to the chemoreceptor cells, and neural elements from the neural crest ectoderm, which give rise to the paraganglionic cells. ${ }^{4}$ As neural crest cells migrate in close association with autonomic ganglion cells, neoplasms arising from these migrating neural crest cells are referred to as paraganglioma or chemodectoma. Therefore, paragangliomas can occur in along the jugular venous system, vagus nerve and ganglia, aortic arch, 
visceral autonomic system and adrenal medulla, apart from the carotid body. ${ }^{5}$ Paraganglioma arising from the carotid body are relatively rare tumors but constitute majority of head and neck paragangliomas. ${ }^{6}$

The carotid body is primarily composed of two cell types: type I and type II. Type I cells (also called glomus or epitheloid cells), measure changes in blood pressure and the composition of arterial blood flowing past them, including the partial pressures of oxygen and carbon dioxide and are also sensitive to changes in blood temperature and $\mathrm{pH}$, suggesting that they are secretory cells. $^{7-8}$ The type II cells (also called sustentacular or supporting cells) resemble glial cells of the nervous system.

Previous investigation showed that the carotid bodies enlarge in cattle, guinea-pigs and rabbits living in the hypobaric hypoxia of high altitude to which they have to acclimatize. ${ }^{10}$ The enlargement of the carotid body also occurs in response to systemic hypertension and hypoxia. ${ }^{11,12}$ These results provide further support for the idea that various elements in the organ are particularly sensitive to hypertension hypoxia.

Human carotid bodies fixed post-mortem, were mostly single or double ovoid shaped, or rarely leaf shaped. ${ }^{13}$ Authors stated that infants who died suddenly have an underdeveloped carotid body. ${ }^{14}$ In the buffalo the carotid body is located in the periarterial connective tissue of the occipital artery immediately cranial to the bifurcation of the common carotid artery. ${ }^{15}$ The carotid body of the camel is located between a mass of loose connective tissue at the point of separation of the internal carotid artery from the carotid trunk. ${ }^{16}$ In the small ruminants it is of a single formation, of an oval, round or irregular shaped parenchymatous organ characterized by its profound vascularity. In most cases it lies on the surface of the medial termination of the common carotid artery. ${ }^{17,18}$ In the pig it, close proximity to the wall of the occipital artery or one of its small proximal branches, has generally very irregular borders but rarely was discrete, adopting an ovoid or crescent-shaped appearance over a limited rostral-caudal part of its extent. ${ }^{19}$ In dogs and beagles the carotid body is arranged in close proximity to the wall of the ascending pharyngeal artery within a divi- sion of connective tissue with definable but irregular borders. Occasionally, it was also observed in relation to the occipital and external carotid arteries in this species. ${ }^{20}$ To date, although some morphological descriptions were carried out on the carotid body of the orders Lagomorpha and Rodentia, there are no studies on this structure of the Angora rabbit. Considering this, the present study was focused on some morphological characteristics of the carotid body of the Angora rabbit..$^{21-27}$

\section{Materials and Methods}

A total of thirteen adult healthy Angora rabbits of both sexes aged 1.5-2 years and weighing between 3.2 and 5.4 $\mathrm{kg}$ were used. All rabbits were obtained from Erciyes University, Veterinary Faculty, Kayseri, Turkey. The animals were intramuscularly anaesthetized with $10 \mathrm{mg} / \mathrm{kg}$ xylazin $\mathrm{HCl}$ (Rompun ${ }^{\circledR}, \mathrm{BAYER}$ ) and $50 \mathrm{mg} / \mathrm{kg}$ ketamin $\mathrm{HCl}$ (Ketanez®, ALKE). Under anaesthesia, they were killed by exsanguination from the abdominal aorta without regaining consciousness. To expose the exact location of the carotid body and its arterial supply in 6 Angora rabbits, red (SetacolorTM, cardinal red, no. 24; PEBEO, Codex, France)-coloured latex (Rubber latexTM; MERCAN, Istanbul, Turkey) was injected into the common carotid artery using conventional methods. Then, they were examined under a stereomicroscope (Nikon SMZ2T, Nikon Corp., Tokyo, Japan). The carotid bodies of other 7 Angora rabbits were excised together with the neighboring arterial vessels for routine histological examinations. The tissue samples were fixed in $10 \%$ bufferedformaldehyde ( $\mathrm{pH}$ 7.4), dehydrated, cleared and embedded in paraffin blocks and cut in 6- $\mu \mathrm{m}$ thick longitudinal sections that were stained with Crossman's trichrome stain. ${ }^{28}$ The histological preparations were examined using a light microscope (Nikon E-400 attached with DS-5M digital camera and DS-L1 Camera control unit).

\section{Results}

In the Angora rabbit the carotid body (Glomus caroticum) that was generally ellipsoid in appearance. In 5 Angora rabbits the carotid body, whose cranial border 
Figure 1. Location of the carotid body between the caudal auricular and the maxillary arteries, right view. a: common carotid artery; b: internal carotid artery; c: linguofacial trunk; d: external carotid artery; e: occipital artery; f: caudal auricular artery; g: maxillary artery; h: Glomic artery; i: glossopharyngeal nerve; k: vagal nerve.

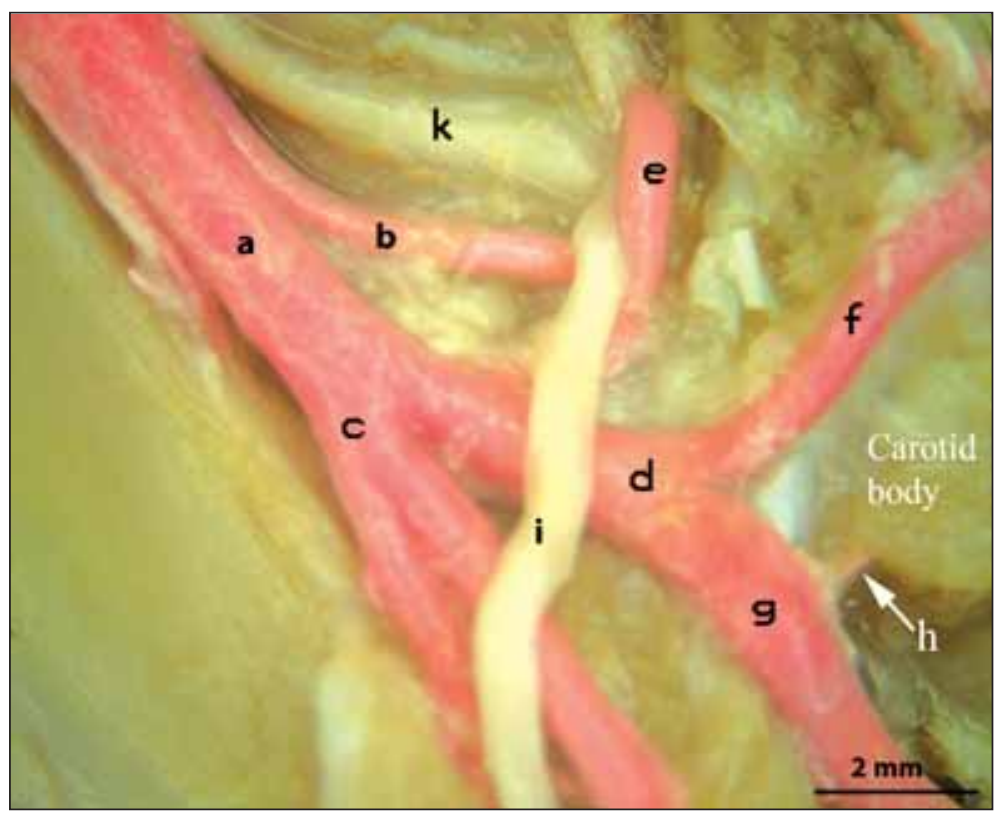

and ventral extremity rested on the caudal auricular and the external carotid arteries, respectively, was buried in the periarterial connective tissue between the occipital and the caudal auricular arteries. In these specimens the carotid bodies were supplied bilaterally by one glomic artery (carotid body artery) originating from the external carotid artery. In 2 Angora rabbits the carotid body was located in a space between the maxillary and the caudal auricular arteries, where its caudal border extended close to the auricular caudal artery and its ventral pole leaned against the maxillary artery (Figure 1). Although blood supply of these two rabbits was furnished bilaterally by one glomic artery from the maxillary artery in principal, the right carotid bodies also received a little contribution from the left caudal auricular artery.

The mean length and width of the carotid body were $1.92 \mathrm{~mm}$ and $0.63 \mathrm{~mm}$, respectively. It was encircled by a capsule-like connective tissue sheath (Glomic capsule) that sends strands in between the parenchyme of this organ and separates lobes and lobules thus making it disseminated in type (Figure 2c).

The parenchymal glomus cells were nearly identical to other paraganglia and included dark or light coloured cells that were divided into type I and type II, respectively. Type I cell was generally grouped around blood sinu- soids and had a large, round or oval-shaped euchromatic nucleus, and contained pinkish granule in its cytoplasm (Figure 3a). Type II cell had long and dark coloured heterochromatic nuclei, which were located slightly off centre and 1-3 in number, and were full of cytoplasmic vacuoles (Figure 3b). Although type II cells that closely resemble Schwann cells were densely accumulated just below the glomic capsule, in the parenchyme they usually surrounded small groups of type I cells.

We have noticed with interest that rich capillary vessels (blood sinusoids) of varying diameter were seen between the islets of the carotid body (Figures 2 and 3), suggesting that there was possibly a functional relation between blood vessel and parenchymal cells of the carotid body.

\section{Discussion}

The carotid body of rabbits was reported to have in close proximity to the wall of the internal carotid artery immediately rostral to the carotid bifurcation, within a division of connective tissue with definable but irregular borders. ${ }^{20}$ However, we recorded that the carotid body of the Angora rabbit nestled mostly between the occipital and the auricular caudal arteries or rarely between the maxillary and the caudal auricular arteries. 


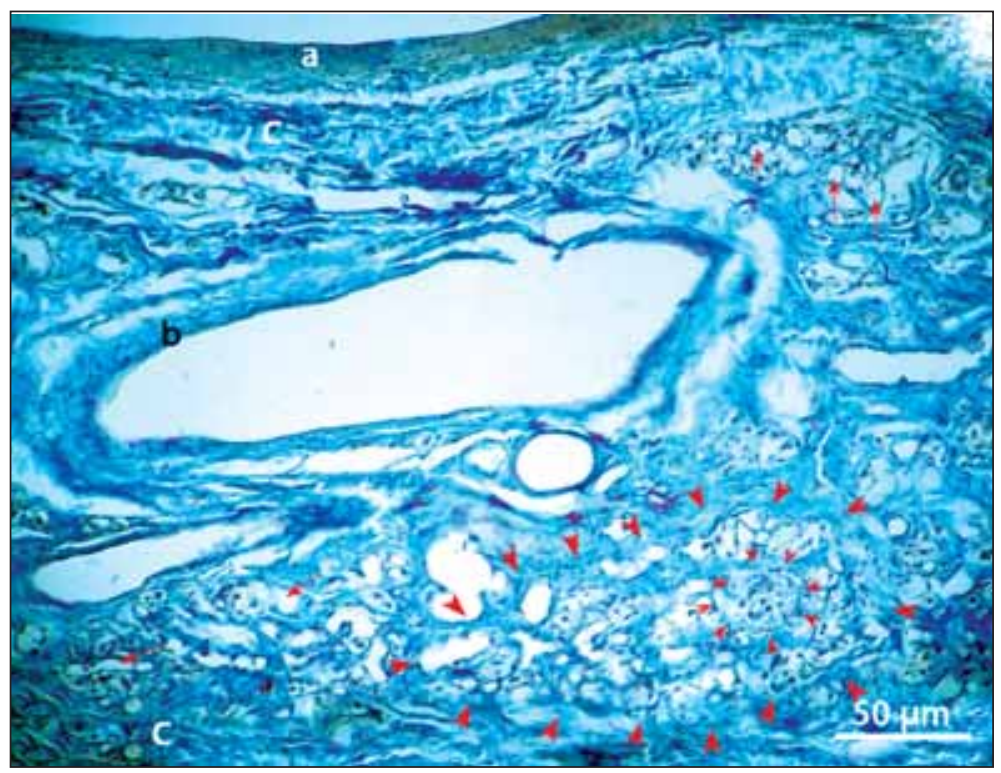

Figure 2. Horizontal section of the carotid body, where it had intimate contact with the occipital artery. a: wall of the occipital artery; b: wall of the glomic artery; c: capsule-like connective tissue sheath (glomic capsule). Arrows show blood sinusoids; thick and thin arrowheads show boundaries of lobe and lobule of the carotid body, respectively.

Both the appearance of types I and II cells and their locations in lobes were consistent with the findings described earlier. ${ }^{18,20,29-30}$

The authors recorded that the carotid body was usually supplied by only one glomic artery which most frequently derived from the external carotid artery, which is in agreement with the results of 5 Angora rabbits. ${ }^{24,26-27}$ Although these researchers also pointed out that its arterial supply was provided more rarely by the common carotid, occipital or internal carotid arteries, the glomic artery of two Angora rabbits arose from the maxillary artery.

Although the glomic artery was recorded to be of elastic type in rabbits, in the Angora rabbit the glomic artery and its feeble branches buried in the carotid body were of muscular type as in the rat and the New Zealand rabbit. $^{24,26-27}$

The glomic artery was reported to have a valve-like intimal cushion of a muscular tube at the level of its ori-

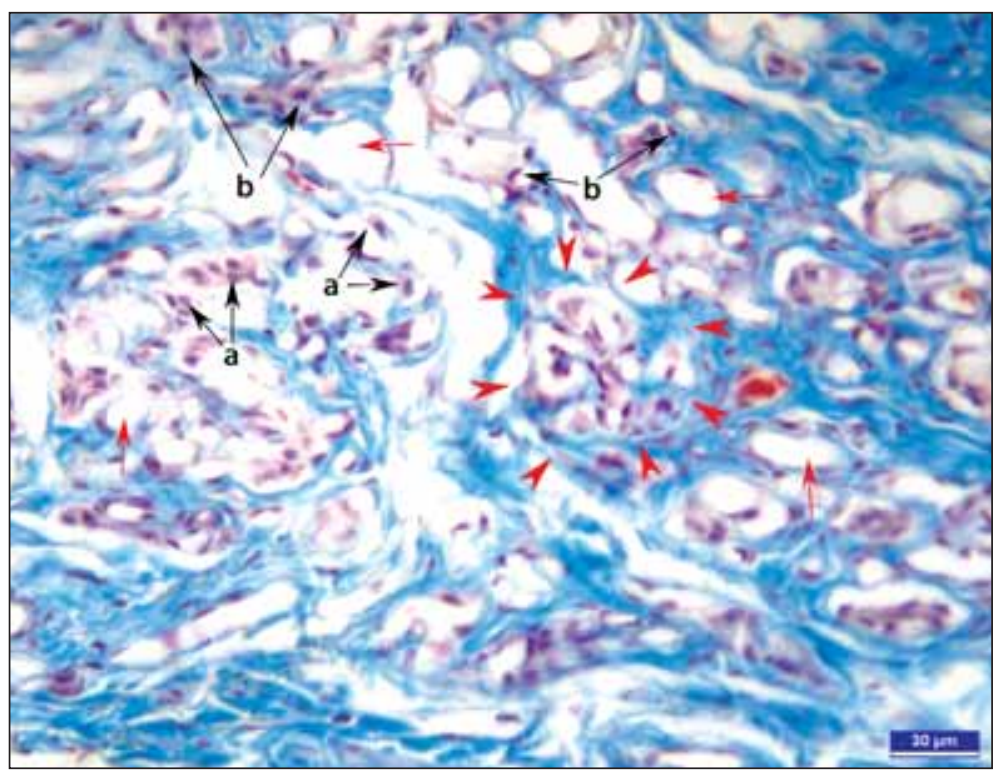

Figure 3. Parenchyme of the carotid body. a: type I cells; b: type II cells. Arrows show blood sinusoids; arrowheads show the boundary of the carotid body lobule. 
gin in the rat, ${ }^{23,26,31-34}$ mice $^{35}$ and $\operatorname{dog} .{ }^{36}$ However, in the Angora rabbit an intimal cushion was observed neither in the glomic artery nor its accessory twigs as reported earlier as in the other rabbits. ${ }^{24,27}$ Although, Unur pointed out that in the New Zealand rabbit a glomic sinus existed at the origin of the glomic artery, which is of elastic type, no glomic sinus was observed in the Angora rabbit. $^{27}$

In conclusion, the results from this study that is the first to be performed on the morphology of the carotid body of the Angora rabbit seem to be shed light on the future studies on the related structure, and to offer a diagnostic approach when distinguishing the rabbit carotid body paraganglioma from other laterocervical neoplasms, and to contribute to the present anatomical knowledge in this species. However, further embryological and physiological studies are needed to reveal exactly the relationship between the morphological and functional alterations of the carotid body.

\section{References}

1. Schlink AC, Liu SM. Angora Rabbits - A potential New Industry for Australia. Rural Industries Research\&Development Corporation (RIRDC), Publication No: 03/014, RIRDC Project No: CSA-19A. 2003.

2. Knight TT, Gonzalez JA, Rary JM, Rush DS. Current concepts for the surgical management of carotid body tumor. Am 7 Surg 2006; 91: 104-10.

3. Kohn A. Die Paraganglien. Arc Mikr Anat 1903; 62: 263-5.

4. Pryse Davies J, Dawson IMP, Westbury G. Some morphologic, histochemical, and chemical observations on chemodectomas and the normal carotid body, including a study of the chromaffin reaction and possible ganglion cell elements. Cancer 1964; 17: 185-202.

5. David AW, Stephen E, Sadhu D, Agarwal S. Surgical management of carotid body tumors: a 15 -year review. Indian 7 Surg 2006; 68: 257-61.

6. Sykes JM, Ossoff RH. Paragangliomas of the head and neck. Otolaryngol Clin North Am 1986; 19: 755-67.

7. Netterville JL, Reilly KM, Robertson D, Reiber ME, Armstrong WB, Childs P. Carotid body tumors: a review of 30 patients with 46 tumors. Laryngoscope 1995; 105: 115-126.

8. Lahiri S, Acker H. Oxygen sensing in the body. Respir Physiol 1999; 115: 255-60.

9. McDonald DM. Structure and function of reciprocal synapses interconnecting glomus cells and sensory nerve terminals in the rat carotid body. In: Coupland RE, Fujita T, eds. Chromaffin,
Enterochromaffin, and Related Cells. Amsterdam: Elsevier; 1976. p. 375-94.

10. Heath D, Smith P, Fitch R, Harris P. Comparative pathology of the enlarged carotid body. 7 Comp Pathol 1985; 95: 259-71.

11. McGregor KH, Gil J, Lahiri S. A morphometric study of the carotid body in chronically hypoxic rats. 7 Appl Physiol 1984; 57: 1430-8.

12. Habeck JO, Przybylski J, Szepek A, Huckstorf C. The aortic bodies of spontaneously hypertensive (SHR) and normotensive rats - a study concerning location and size. Anat Anz 1991; 172: 281-5.

13. Khan Q, Heath D, Smith P. Anatomical variations in human carotid bodies. 7 Clin Pathol 1988; 41: 1196-9.

14. Pavai Z, Toro K, Keller E, Jung J. Morphometric investigation of carotid body in sudden infant death syndrome. Rom 7 Morphol Embryol 2005; 46: 93-7.

15. Prakash P, Rao GS. A morphological study of the carotid body and the fibre content of carotid nerve in the buffalo. Acta Anat 1976; 95: 249-59.

16. Etemadi, A. A. Carotid body of Camelus dromedaries. Acta Anat 1975; 92: 110-21.

17. Molenda O. Morphology and topography of the carotid body and carotid sinus in sheep (Ovis ammon f. aries L., 1758). Pol Arch Weter 1975; 18: 343-64.

18. Abdel-Magied EM, Taha AA. Ultrastructure of the carotid body of the goat. Anat Histol Embryol 1995; 24, 159-64.

19. Clarke JA, De Burgh Daly M. The carotid body of the mini-pig. Anat Anz 1990; 170: 339-47.

20. Clarke JA, De Burgh Daly M. Distribution of carotid body type I cells and periadventitial type I cells in the carotid bifurcation regions of the dog. Acta Anat 1982; 113: 352-70.

21. Lever JD, Lewis PR, Boyd J. Observations on the fine structure and histochemistry of the carotid body in the cat and rabbit. 7 Anat 1959; 93: 478-90.

22. Clarke JA, De Burgh Daly M. Distribution of carotid body type I cells and other periadventitial type I cells in the carotid bifurcation regions of the rabbit. Cell Tissue Res 1981; 216: 603-14.

23. Taguchi $T$. Blood vascular organization of the rat carotid body: a scanning electron microscopic study of corrosion casts. Arc Histol 7pn 1986; 49: 243-54.

24. Habeck J. A comparison of the blood supply of the carotid body in rats and rabbits. Anat Anz 1987; 164: 313-22.

25. Şeker M, Pallot DJ, Habeck OJ, Abramovici A. Effects of various diseases upon the structure of the human carotid body Adv Exp Med Biol 1994; 360: 353-5.

26. Unur E, Aycan K. Arteries of the carotid body in rats. Anat Histol Embryol 1999; 28: 167-9.

27. Unur E. Morphological investigations of carotid body and its arteries in rabbits. Anat Histol Embryol 2002; 31: 266-8.

28. Culling CFA, Allison RT, Barr WT. Cellular Pathology Technique. London: Butterworth \& Co. Ltd; 1985. 
29. Abraham A. Light- and electron-microscopic investigations on human carotid bodies. Z Mikrosk Anat Forsch 1981; 95: 33-71.

30. Pallot DJ, Şeker M, Abromovici A. Post-mortem changes in the normal rat carotid body: possible implications for human histopathology. Virchows Arc Pathol Anat Histopath 1992; 420: 31-5.

31. Hesse M, Böck D. Studies on inta-arterial cushions. III. The cushions at the origin of the carotid body artery (CBA). Z Mikrosk Anat Forsch 1980; 94: 471-8.

32. McDonald DM, Larue DT. The ultrasucture and connections of blood vessels supplying in the rat carotid body and carotic sinus. $\mathcal{F}$ Neurocytol 1983; 12: 117-53.
33. Habeck JO, Honig A, Huckstorf C, Pfeifer C. Arteriovenous anastomoses at the carotid bodies of rats. Anat Anz 1984; 156: 209-15.

34. Smith P, Jago R, Heath D. Glomic cells and blood vessels in the hyperplastic carotid bodies of spontaneously hypertensive rats. Cardiovasc Res 1984; 18: 471-82.

35. Böck P. Das glomus caroticum der maus. Adv Anat Embryol Cell Biol 1973; 48: 1-84.

36. Serafini Fracassini A, Volpin D. Some features of the vascularisation of the carotid body in the dog. Acta Anat 1966; 63: 571-9.

Correspondence to: Emrullah Eken, PhD

Department of Anatomy, Faculty of Veterinary Medicine, University of Selçuk, Campus 42279 Konya, Turkey Phone: +90 33222336 17; Fax: +90 3322410063 e-mail: eeken@selcuk.edu.tr

Conflict of interest statement: No conflicts declared. 